\title{
Determining the Origin of Seafood Products on the Belgian Market: Challenges to Traceability and Database Management
}

\author{
I. Sioen ${ }^{* 1,2}$, W. Verbeke ${ }^{3}$, S. De Henauw ${ }^{1}$, K. Parmentier ${ }^{4}$, M. Raemaekers ${ }^{5}, J^{2}$. Willems ${ }^{1}$ and \\ J. Van Camp ${ }^{2}$
}

\author{
${ }^{I}$ Department of Public Health, Ghent University, Belgium; ${ }^{2}$ Department of Food Safety and Food Quality, Ghent Uni- \\ versity, Belgium; ${ }^{3}$ Department of Agricultural Economics, Ghent University, Belgium; ${ }^{4}$ ILVO, Sea Fisheries Depart- \\ ment, Belgium; ${ }^{5}$ FAVV, Belgium
}

\begin{abstract}
In countries where the majority of the seafood is imported, information about seafood origin is important in particular from a food safety perspective. In the case of Belgium, no database is available describing the origin of commercial seafood products. This investigation to determine the origin revealed three important problems. First, information needed to stem from different non-related databases; second, import countries did not define fishing grounds or product sites; third, seafood may have transited many areas and no information was available on this. Since European traceability regulations have been established for seafood, some limited extra efforts with respect to data collection and management can lead to (inter)national databases making seafood traceability information more practically useful, for example towards public health policy making.
\end{abstract}

Keywords: Traceability, seafood, Belgium, fishing grounds, import.

\section{INTRODUCTION}

The regular consumption of fish and other seafood has been promoted during the last decades because they contain proteins of high biological value, are rich in certain minerals and vitamins, low in saturated fatty acids and are an excellent source of long chain omega-3 polyunsaturated fatty acids, which have been associated with cardiovascular health benefits [1]. At the same time, seafood products are a dietary source of carcinogenic (e.g. dioxins and polychlorinated biphenyls (PCBs)) and non-carcinogenic (e.g. methyl mercury) contaminants. Both properties depend in part on the origin of the seafood [2]. For example, since PCBs and dioxins originate from human and industrial activities, fishing grounds in the vicinity of industrially developed regions are more contaminated with these contaminants than others [3]. Since Belgium is a small country with a very small coast line and only three commercial seafood harbours, a large part of the seafood available on the Belgian market is imported from other countries. Moreover, the current seafood supply and food supply in general is characterized by an increasing globalization, with increasing international trade, often hampering adequate and detailed food traceability. Specifically, seafood is the most traded of all food commodities [4]. A better understanding of fisheries trade flows would, therefore, be helpful in attempts to examine the interactions between trade, fisheries management, and marine ecosystems [5], and to use this information in epidemiological and food safety related work. Moreover, a recent study by Jacquet and Pauly [6] indicated that trustworthy information and watertight guarantees with respect to seafood origin are crucial with respect to consumer protection, and could be highly relevant towards public health policy.

\footnotetext{
*Address correspondence to this author at the Department of Food Safety and Food Quality, Ghent University, Belgium;

E-mail: isabelle.sioen@ugent.be
}

In this study, the focus lies on the aim to make seafood traceable on a more specific level, i.e. country of origin as well as fishing ground. In general, traceability information is of interest from environmental perspectives, food safety perspectives, for public health policy and supply chain management. This specific study was performed within a project investigating the food safety and public health aspects of seafood consumption by the Belgian population.

Traceability is defined as 'the ability to trace the history, application, or location of what is under study' (ISO 9000) $[7,8]$. Nowadays, traceability has become part of any good quality management system since it aims to follow the product in each step of the supply chain. The Codex Alimentarius Commission [9] defined traceability or product tracing as "the ability to follow the movement of a food through specified stage(s) of production, processing and distribution".

The introduction of traceability into the food supply chain is a relatively new concept, whereas traceability systems have been used for many years in several other sectors such as aviation, automobile, and pharmaceutical industry [7]. Globalization of trade and the lack of international standards have made identifying the origin and history of seafood products difficult, raising concerns from retailers, food service providers, and consumers about the safety of their seafood supplies. It is clear that traceability could be an important strategy to address consumer concerns about the quality of the supplied seafood and the declining fish populations in the wild, as well as to address growing pressure from consumers to produce sustainable food [8]. Pàlsson et al. [10] reported that the seafood industry happened to use mainly paper based traceability systems during the nineties. Although this is gradually changing owing to information and communication technology advancements [11], important barriers to its application in the field and in practice persist. Software systems allowing for the integration of financial and production data in one software package are typi- 
cally too costly for the small business units in fisheries or in the fish and aquaculture industry [7]. Furthermore, questions rise as to how artisan and small exploitations at the primary production level can cope with regulatory and contractual traceability requirements [12]. Nevertheless, rapid developments in information technology, standardised data management, transmission and archiving protocols, as well as physical labelling and encoding systems, such as RFID-tags as data carriers, have fostered the technological feasibility of traceability, even in the case of seafood [13-15]. Also, new tools relating to genomics, such as molecular genetics, DNAmarker technology and proteomics allow for species identification, claim authenticity testing and verification of labelling and certification schemes [16-18]. Whereas from a technological point of view the necessary procedures, tools and instruments seem to be available, major challenges still pertain to the economic feasibility and potential market benefits of traceability beyond legal requirements, which depends for a major part on consumer willingness to pay for greater access to information about the origin and history of seafood products $[8,19]$.

In 2001, the European Commission [20] published a regulation laying down detailed rules about the information that has to be supplied to the consumer about fishery and aquaculture products (Commission Regulation EC 2065/2001). This regulation determines that appropriate marking or labelling for seafood products has to indicate the commercial designation of the species, the production method (wild caught at sea or in inland waters versus farmed or from aquaculture), and the fishing ground where it was caught or produced. The latter must be documented as follows: for fish caught at sea, the FAO area (for more details see later) must be stated; for fish from inland waters the country of origin must be provided; and for farmed fish the country of the final development (i.e. the last step in the processing) of the product must be given [7]. This information must be indicated on the label or posted up in the case of fresh fish sold in bulk, e.g. in retail or fish monger shops. Horizontal traceability requirements, i.e. the requirement of being able to trace down from requirements to implementation and up from implementation to requirements (and all points in-between), were introduced by the European Union in its Regulation EC 178/2002, which has been in force since January 1,2005 . These requirements apply to all types of food, including seafood.

The European regulation involves that for all the consumable fish on the Belgian market, information must be available describing the fishing ground or production country where the commercial seafood products were caught or produced. This regulation concerns individual products. Up to now, however, no aggregate database is available describing quantitatively the origin of the seafood species available for consumption in Belgium; and to the authors' knowledge no publications describe the existence of such a database in other countries.

Moreover, a pan-European study by Euroconsumers showed that incorrect labelling of seafood products was the rule rather than the exception in 2006: almost $90 \%$ of the seafood samples collected from Belgian retail outlets were labelled incorrectly [21]. Also a recent Norwegian study evaluated the traceability systems in the supply chain of the
Norwegian fish industry and food retail trade and showed that traceability labelling was unsatisfactory. Almost $40 \%$ of the considered fish products could not be traced back to the fishing vessel or the fish farmer [22].

The initial aim of the work reported in this paper was to investigate the origin of the seafood products available on the Belgian market. However, during the study, it became clear that many impediments exist which made the detailed execution of this work difficult. The current paper, therefore, focuses on the procedure followed, the preliminary results obtained, and resulting recommendations related to extra data needed to improve seafood traceability on an aggregate level and any subsequent analyses related to benefits and/or risks depending on seafood origin in the future.

\section{METHODOLOGY}

On the basis of food consumption data available in Belgium, 41 seafood species and two fish products (caviar and surimi) were considered relevant for this study due to their regular consumption (Table $\mathbf{1}$ ).

In order to gather information about the origin of these commercial seafood species and products available on the Belgian market, four different data sources were combined. These concern two national databases: (1) An economic database from the Central Economic Council (CEC) which is part of the Ministry of Economic Affairs of Belgium (received in November, 2004) [23]; (2) Data on landings in Belgian harbours, provided by the Sea Fisheries Department of the federal Agricultural Research Centre (received in November, 2004); and two international databases: (3) The landings/production databases of seafood from the Food and Agricultural Organisation (FAO) [24] (together with the software FishStat Plus Version 2.3) (www.fao.org; consulted in January 2005); and (4) Catch data from the International Council for the Exploration of the Sea (ICES) (www.ices.dk; consulted in January 2005) [25].

The economic CEC-database resulted into an Excel-file containing Belgian import and export data of all seafood products (fresh, frozen, and canned). The database contained for each seafood product the flow (import or export), the product name (mentioning one or more scientific names of seafood species), the Dutch name, the country of import or the country to which it was exported, the amount in tons imported or exported, and the value in euros. The FAO provided data about the annual catching and production of all different seafood species by all countries. ICES collected annual landings data on the level of sub areas within the Northeast Atlantic Sea including over 200 species officially submitted by 19 ICES Member States. For this study, a combination was made of different FAO-datasets and the ICESdataset in order to link this combined datasets with the CECdata and describe as detailed as possible the catching and production of seafood with respect to the various fishing grounds.

The applied methodology consisted of two consecutive steps. In a first step, the countries of origin were determined for the seafood products on the Belgian market. In a second step, an attempt was made to express their origin in terms of fishing grounds. To illustrate the methodology, an elaborated example for cod, one of the most consumed seafood species in Belgium, is given in the appendix of this paper. 
Table 1. Nomenclatural Table of 41 Seafood Species, Relevant for Belgian Consumption

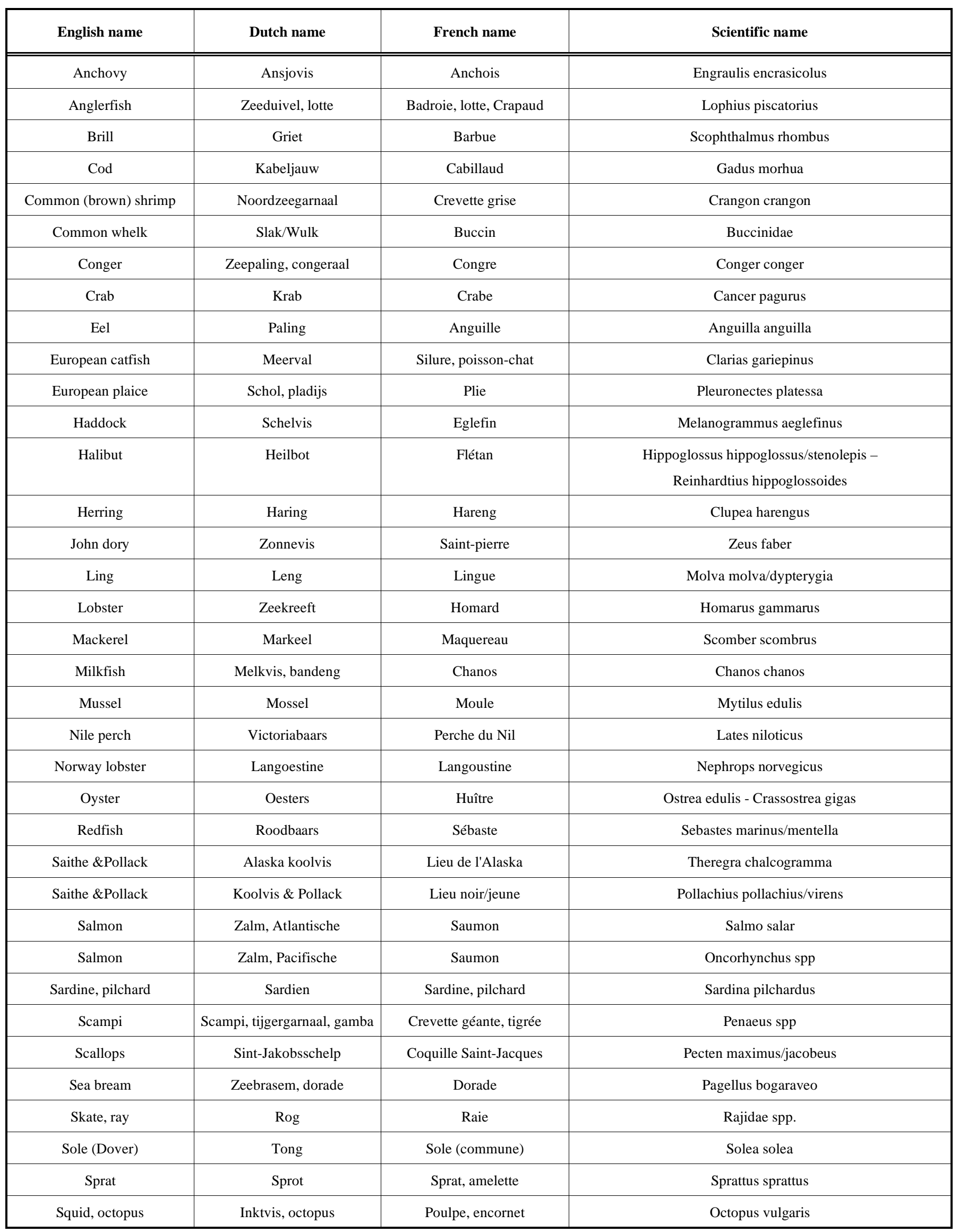


(Table 1). Contd.....

\begin{tabular}{|c|c|c|c|}
\hline English name & Dutch name & French name & Scientific name \\
\hline Squid, octopus & Inktvis, pijlinktvis & Calmar & Loligo forbesi/vulgaris \\
\hline Squid, octopus & Inktvis, zeekat & Sèche & Sepia officinalis \\
\hline Swordfish & Zwaardvis & Espadon & Xiphias gladius \\
\hline Tilapia & Tilapia & Tilapia & Oreochromis niloticus/aureaus/mossambica \\
\hline Trout & Forel & Truite & Salmo trutta \\
\hline Trout, rainbow & Forel, regenboog- & Truite arc-en-ciele & Oncorhynchus mykiss \\
\hline Tuna & Tonijn & Thon & $\begin{array}{l}\text { Thunnus albacares/alalunga/maccoyii/obesus/thynnus - } \\
\text { Katsuwonus pelamis }\end{array}$ \\
\hline Turbot & Tarbot & Turbot & Scophthalmus maximus, Psetta maxima \\
\hline Whiting & Wijting & Merlan & Merlangius merlangus \\
\hline Wolf fish & Zeewolf & Loup de mer & Anarhichas lupus \\
\hline
\end{tabular}

\section{Defining the Countries of Origin}

With respect to seafood imports, only the import data from other countries into Belgium were taken into account, thus excluding landing data (i.e. no catching data of the Belgian fleet), since the latter were available with more details from the Belgian Sea Fisheries Department (expressed in the same terms as the FAO classification). A large amount of the imported seafood is, however, again exported. Lacking more detailed information, the assumption had to be made that exporting seafood products from Belgium to other countries (whether it were own landings or imports) did not change the country's proportional import share. Only the data of the year 2000 were used, describing quantitatively the different countries of import for each seafood product on the Belgian market in 2000 . For each seafood product the ratio originating from each country of interest was computed as a percentage.

\section{Defining the Fishing Grounds of Origin}

The FAO defines worldwide 24 different fishing grounds. Six codes describe a zone of inland waters and 18 describe a sea or a part of an ocean (Table 2 and Fig. 1). This FAO classification was applied to describe the origin in the second step. In addition, it was of interest to subdivide four fishing grounds and define the origin by their subdivisions: the North-eastern Atlantic Ocean, the Eastern Central Atlantic Ocean, the South-eastern Atlantic Ocean, and the Mediterranean \& Black Sea, since they are important regions of origin for the seafood on the Belgian market.

As such, smaller seas, e.g. the Baltic Sea and the North Sea, became separated entities and were not just considered together with a lot of other seas such as the North-eastern Atlantic Ocean. The relative amounts per country were converted to relative amounts per fishing ground by applying the combined dataset of the FAO data and the ICES.

Therefore, a second assumption had to be made, considering that the country of import is the same as the country of origin (assuming that there was no transit). The data were sorted per species (based on the scientific name) and per country. For each of these species-country combinations the amounts caught or produced per fishing ground were given in tons.

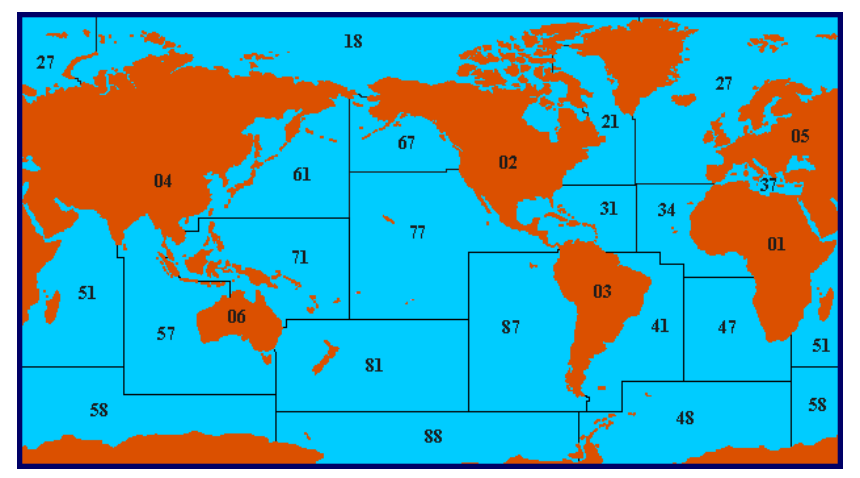

Fig. (1). The 24 international fishing grounds as defined by FAO (www.fao.org).

In summary, two databases were constructed (CEC2000 and FAO2000). CEC2000 describes the amount imported from all relevant countries (species-country combination), for each seafood product on the Belgian market (defined by a product name). FAO2000 describes the amount caught or produced in each relevant fishing ground (species-countryfishing ground combination), for each seafood species and all countries all over the world. These two databases were then linked to each other at the level of species and country by creating $101 \mathrm{Sp}$-codes (Species-codes) and 1022 unique SpC-codes (Species-Country-codes). As such, the speciescountry combinations in both files could be described by that code. Subsequently, the distribution per SpC-code out of CEC2000 over the different fishing grounds was calculated case by case by multiplying the amount imported in ton by the relative percentage caught or produced by that country over the different fishing grounds (found by looking up the corresponding SpC-code in FAO2000). Up to this point in the procedure, the data describing the landings in the Belgian harbours in 2000 were not taken into account. These data were available in a database already split up per fishing ground. Subsequently, these data were added to the newly 
composed database. Thereupon, for each Sp-code the distributions over the fishing grounds were summated in order to get the overall division per species without the separation per country. Finally, the relative percentages for each species per fishing ground were calculated to meet the final objective of the study.

Table 2. Area Codes and Names of the 24 International Fishing Grounds all Over the World (www.fao.org)

\begin{tabular}{|c|c|c|}
\hline & Area code & Area name \\
\hline \multirow{6}{*}{ 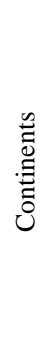 } & 1 & Africa - Inland waters \\
\hline & 2 & America, North - Inland waters \\
\hline & 3 & America, South - Inland waters \\
\hline & 4 & Asia - Inland waters \\
\hline & 5 & Europe - Inland waters \\
\hline & 6 & Oceania - Inland waters \\
\hline \multirow{18}{*}{ 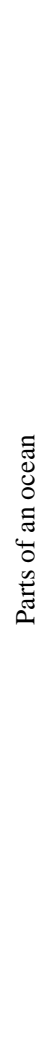 } & 21 & Atlantic, Northwest \\
\hline & 27 & Atlantic, Northeast \\
\hline & 31 & Atlantic, Western Central \\
\hline & 34 & Atlantic, Eastern Central \\
\hline & 37 & Mediterranean and Black Sea \\
\hline & 41 & Atlantic, Southwest \\
\hline & 47 & Atlantic, Southeast \\
\hline & 48 & Atlantic, Antarctic \\
\hline & 51 & Indian Ocean, Western \\
\hline & 57 & Indian Ocean, Eastern \\
\hline & 58 & Indian Ocean, Antarctic \\
\hline & 61 & Pacific, Northwest \\
\hline & 67 & Pacific, Northeast \\
\hline & 71 & Pacific, Western Central \\
\hline & 77 & Pacific, Eastern Central \\
\hline & 81 & Pacific, Southwest \\
\hline & 87 & Pacific, Southeast \\
\hline & 88 & Pacific, Antarctic \\
\hline
\end{tabular}

\section{FINDINGS}

\section{Countries of Import}

From the CEC 2000 data, it appeared that - in the year 2000 - 219,000 tons of seafood was imported from 116 countries, geographically spread over the five continents and 26,000 tons seafood was landed in Belgian harbours. This yields a total amount of 245,000 tons of seafood entering Belgium in 2000 from which $89 \%$ was imported. Of the total Belgian imports and landings, $90 \%$ was contributed by only 22 countries (Belgium inclusive) (Table 3), 71\% of which originated from European countries. When different product groups are considered, it appeared that $98 \%$ of the crustaceans and shellfish was imported, and finfish imports accounted for $85 \%$ of the total finfish supply.

As shown in Table $\mathbf{3}$, more than $50 \%$ is supplied by Belgium and three European countries: The Netherlands, France, and Denmark. It is important to repeat that the table describes the countries of import, not of origin. Of the total amount of 245,000 tons of seafood entering in Belgium, 40\% (99,000 tons) were subsequently exported to other countries, leading to 146,000 tons available on the Belgian market for consumption. This is roughly $14.6 \mathrm{~kg} / \mathrm{year} / \mathrm{caput}$ or 280 g/week/caput.

\section{Fishing Grounds of Origin}

Two assumptions had to be made before distributing the imported seafood products on the Belgian market over the different fishing grounds expressing their origin. The first one involved assuming that the country of import did not differ from the country where the seafood was captured or produced. It should be noted that this assumption is not correct in all cases since it is known that several countries import raw fish from a country with an extensive seafood capture or production capacity to process them (peeling of shrimps, filleting of fish ...) and export post processing. However, as no quantitative information was available concerning the transit of seafood products, there was no alternative for this assumption.

A second assumption was related to the observation that a large amount of fish imported or caught in Belgium is exported back again to other countries. This hampers the determination of the origin of marine food products, since it is unknown what the origin of the exported products really is: they may be landed, or imported from various countries. The assumption was made that exporting a certain seafood species out of Belgium to other countries (whether it were own landings or imports) did not change the ratio describing the different countries of origin for that species.

Taking into account the assumptions made, the combination of the estimated data indicated that more than $50 \%$ of the seafood products on the Belgian market originated from the Northeast Atlantic Area, with the North Sea being the most important sub area (accounting for 13\%). Fig. (2) shows the results for two individual fish species frequently consumed in Belgium. This figure indicates that almost all cod available on the Belgian market origins from the Northeast Atlantic Sea. Tuna originates from many different FAO areas, with the Eastern Central Atlantic Sea contributing most of the tuna available on the Belgian market.

\section{DISCUSSION AND FUTURE DIRECTIONS}

Even when any remaining technological barriers or practical issues in the implementation of seafood traceability could be lifted, and despite the new and stringent EU legislation dealing with seafood traceability, labelling and information provision, the composition of an aggregate electronic database bringing together all relevant information on an (inter)national level remains a major challenge related to the traceability of commercial seafood. The current lack of such a database causes problems to determine the origin of seafood products on an aggregate level, and might also hamper 
Table 3. The 22 Most Important Countries Supplying Seafood for the Belgian Market, with their Percentage Supplied Relative to the Total Amount ( $\%$ of 245,000 Tons)

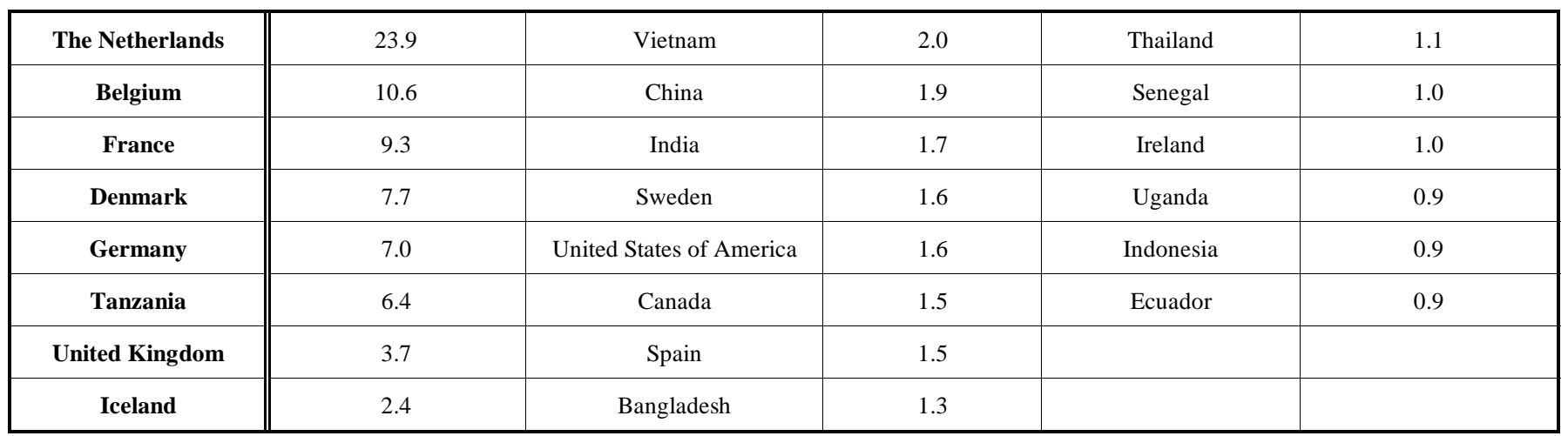
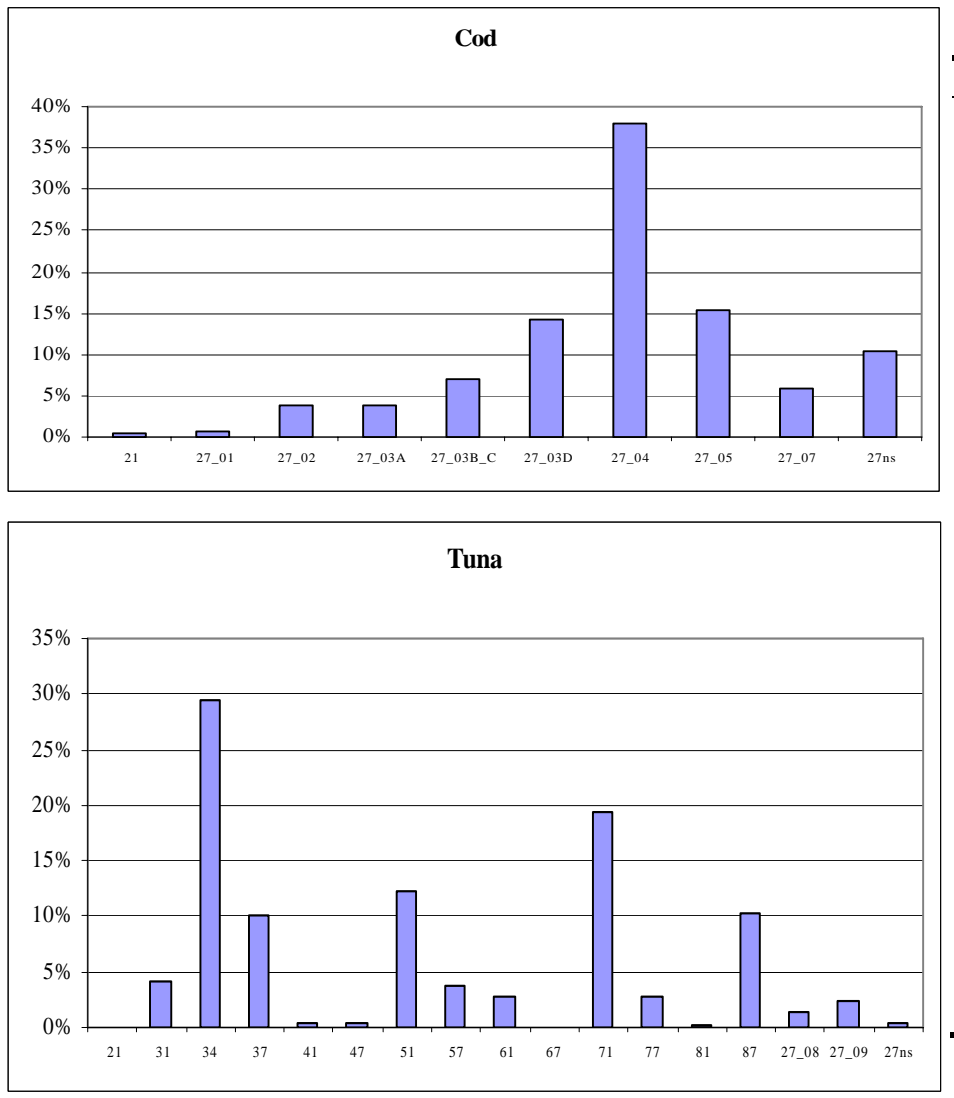

\begin{tabular}{ll}
\hline Area code & Area name (FAO) \\
\hline 21 & Atlantic, Northwest \\
27 & Atlantic, Northeast \\
$27 \_01$ & Barents Sea \\
$27 \_02$ & Norwegian Sea, Spitsbergen \\
27_03A & \& Bear Island \\
27_03B_C & Skagerrak and Kattegat \\
27_03D & Sont and Belten \\
$27 \_04$ & Baltic Sea \\
$27 \_05$ & North Sea \\
$27 \_07$ & Iceland and Faroer Islands \\
$27 \_08$ & Irish Sea and coast \\
$27 \_09$ & Gulf of Biskaje \\
31 & Portuguese coast \\
34 & Atlantic, Western Central \\
37 & Atlantic, Eastern Central \\
41 & Mediterranean and Black Sea \\
47 & Atlantic, Southwest \\
51 & Atlantic, Southeast \\
57 & Indian Ocean, Western \\
61 & Indian Ocean, Eastern \\
67 & Pacific, Northwest \\
71 & Pacific, Northeast \\
77 & Pacific, Western Central \\
81 & Pacific, Eastern Central \\
87 & Pacific, Southwest \\
\hline
\end{tabular}

Fig. (2). The calculated origin of two frequently consumed fresh fish species in Belgium (in \%).

withdrawal or recall of defective or hazardous products, as well as adequate consumer and public health policy decisionmaking. Moreover, even if the traceability data resulting from European legislation had led to a consistent database, the enforced level of detail might not be sufficient, e.g. the Baltic Sea cannot be distinguished from the North Sea, since both fishing grounds are located in the FAO area Northeastern Atlantic Ocean. Moreover, it seems that this problem is not a new one, and also exists beyond the boundaries of Europe, since American researchers also concluded that landings by the seafood industry are difficult to manage [26].
Morrissey [27] addressed the role of traceability and indicated that the systems are in place and possess of the necessary features from a technological point of view to safeguard and guarantee seafood origin. Our study demonstrates that, despite the technological developments and recent legislative advances in this respect within the EU, traceability systems and their potential benefits towards policy making are still largely underexploited. It still appears extremely difficult to trace the origin of seafood products on an aggregate market level. Therefore, we call for extending the use of the valuable traceability information that is already available, 
so as to make this information more suitable e.g. through international databases, to be used for public health and marketing policy purposes and to make traceability more valuable for policy making.

Lupin [12] notes that "despite the noticeable development of traceability systems, some important questions remain open, particularly at the level of international food and seafood trade". Apart from regulatory issues, approvals of principles and practical applications, one of these open questions relates to the establishment of centralised aggregate databases. Our study made clear that it is extremely hard even in the case of a small and well-defined market such as the Belgian one - to determine the real origin of commercial seafood products until consumers' dishes; this, in spite of all existing regulations concerning traceability of food items and the marking and labelling of commercial food products. Examples of voluntary chain traceability systems and investigations with respect to what data should follow a fish product through the chain from catch/farming to consumer are available (e.g. TRACEFISH). Nevertheless, to the authors' knowledge, no aggregate market-level databases covering fish species, volumes and origin are available. In absence of such a clear and useable database, this study has aimed at establishing the origin of seafood products on the Belgian market. Therefore, efforts were made to collect and link data from different sources.

Even though the market under consideration is rather small and well defined, important problems were encountered. First, the information needed came from different, non related sources, which can hardly be linked. Second, countries of import did not necessarily specify the fishing grounds or production sites of their export products and several assumptions had to be made in this respect. Third, even when one would be able to retrieve detailed information about the origin of seafood in terms of fishing grounds, the relevance of this information remains uncertain since seafood species caught at a certain fishing ground might have transited many others during their life. In the future, more information describing the transit of seafood products between different countries is necessary in order to find out the origin of the products. Finally, the specific purpose of studying the origin of seafood products was to use the numerical results for the assessment of the intake of nutrients and contaminants via seafood consumption. Especially with respect to exposure to contaminants, thus from a public health perspective, information about seafood origin is crucial since contaminant levels vary across different origins much more than nutrient levels. This also necessitates the availability of contaminant concentration data in seafood products specifying the related fishing grounds. One of the major outcomes of this study is that it revealed the current problems encountered when aiming to describe the origin of seafood on a consumer market of national level.

It is indeed a particular challenge to investigate on the traceability of seafood on national markets, since seafood is both the most traded food item globally, which furthermore offers substantial health benefits, but also eventual safety risks (e.g. a too high contaminant intake when fatty fish is consumed unlimited) for consumers. Moreover, since regulations have recently been enacted on the European level to trace and label seafood with its origin, some extra efforts on the level of data collection can hopefully lead to the composition of (inter)national databases based on seafood traceability information. Such information databases would definitely mean substantial added value besides traceability as such, and make traceability information valuable besides the classical tracking and tracing of products. When efforts would be performed to establish such databases, it will be of interest to label the origin of the seafood on such a level of detail that it becomes more meaningful for consumers, policy makers and researchers in the field of public health. The latter is relevant since Belgian consumers, in particular those with high importance attached to ethical and sustainability issues, are interested in more information about the production method and the origin [28]. Our exercise has exemplified that it is possible to determine the origin of seafood products in a particular market. More importantly though, this case has demonstrated that several difficulties were encountered and numerous assumptions (some of which might not perfectly hold in reality) had to be made, for determining the origin of seafood products on a particular market. Therefore, the main contribution of this paper pertains to identifying limitations and questions, which hopefully can be solved in the near future through taking benefit as much as possible of the numerous mandatory and voluntary traceability systems that have been established recently.

\section{ACKNOWLEDGEMENTS}

There were no conflicts of interest. The authors gratefully acknowledge financial support from the Belgian Science Policy through the SPSD II project CP/02/56 and the Institute for the Promotion of Innovation through Science and Technology in Flanders (IWT-Vlaanderen). Part of this work has been performed within the Integrated Research Project SEAFOODplus, contract FOOD-CT-2004-506359. Partial financing by the EU is gratefully acknowledged.

\section{REFERENCES}

[1] Ruxton CHS, Calder PC, Reed SC, Simpson MJA. The impact of long-chain n-3 polyunsaturated fatty acids on human health. Nutr Res Rev 2005; 18(1):113-129.

[2] Sioen I, Van Camp J, Verdonck FAM, Van Thuyne N, Willems JL, De Henauw SWJ. How to Use Secondary Data on Seafood Contamination for Probabilistic Exposure Assessment Purposes? Main Problems and Potential Solutions. Hum Ecol Risk Assess 2007; 13(3):632-657.

[3] Karl H, Ruoff U, Bluthgen A. Levels of dioxins in fish and fishery products on the German market. Chemosphere 2002; 49(7):765773.

[4] Nierentz J. The growth of aquaculture: A global perspective. Paper presented at: Future Aquaculture conference, 14-15 September, Duino (Trieste), Italy. 2006.

[5] Marsden AD, Sumaila UR. Tracking flows of fisheries products: the case of Pacific halibut in the Canadian economy. Fish Res 2005; 73(1-2):259-264.

[6] Jacquet JL, Pauly D. Trade secrets: Renaming and mislabeling of seafood. Marine Policy 2007, in press.

[7] Frederiksen M, Gram L. Traceability. In: Huss HH, Ababouch L, Gram L, editors. Assessment and management of seafood safety and quality. Rome: FAO, 2003: 210-215.

[8] Thompson M, Sylvia G, Morrissey MT. Seafood traceability in the United States: Current trends, system design, and potential applications. Compr Rev Food Sci Nutr 4(1):1-7.

[9] Codex Alimentarius Commission. Report of the 27th Session Joint FAO/WHO Food Standards Programme, 28 June - 3 July, Geneva, Switzerland. 2004. Rome, Codex Alimentarius Commission.

[10] Pàlsson PG, Storoy J, Frederiksen M, Olsen P. Traceability and electronic transmission of qualitative data for fish products. The 
Nordic Minister Council, editor. Status report nr.3, 1-22. 2000. Tromso, Norway, The Nordic Minister Council.

[11] Cibot C, Kolypczuk L. Seafood freshness and traceability for consumer safety. Sci Aliments 2003; 23(4):535-541.

[12] Lupin H. Traceability. Document presented at the Tenth Session of Committees on Fisheries, Sub-Committee on Fish Trade, 30 May-2 June, Santiago de Compostella, Spain. 2006.

[13] Frederiksen M, Osterberg C, Silberg S, Larsen EH, Bremner HA. Development and validation of an internet based traceability system in a Danish domestic fresh fish chain. J Aquat Food Prod Tech 2007; 11:13-34.

[14] Børessen T, Frederiksen M, Larsen EH. Traceability from catch to consumer in Denmark. In: Luten JB, Oehlenschlager J, Olafsdottir G, editors. Quality of fish from catch to consumers. Wageningen: Wageningen Academic Publisher, 2003: 93-100.

[15] Denton W. Tracefish: the development of a traceability scheme for the fish industry. In: Luten JB, Oehlenschlager J, Olafsdottir G, editors. Quality of fish from catch to consumers. Wageningen: Wageningen Academic Publisher, 2003: 75-91.

[16] Hayes B, Sonesson AK, Gjerde B. Evaluation of three strategies using DNA markers for traceability in aquaculture species. Aquaculture 2005; 250(1-2):70-81.

[17] Martinez I, Friis TJ. Application of proteome analysis to seafood authentication. Proteomics 2004; 4(2):347-354.

[18] Maldini M, Nonnis Marzano F, Fortes GG, Papa R, Gandolfi G. Fish and seafood traceability based on AFLP markers: Elaboration of a species database. Aquaculture 2006; 261(2):487-494.

[19] Caswell JA. Quality assurance, information tracking, and consumer labeling. Mar Pollut Bull 2006; 53(10-12):650-656.
[20] European Commission. Commission Regulation (EC) No 2065/2001 of 22 October 2001 laying down detailed rules for the application of Council Regulation (EC) No 104/2000 as regards informing consumers about fishery and aquaculture products. L 278/6. 22-10-2001. Brussels, European Commission.

[21] Jooken K, Lauryssen S. Aquacultuur en etikettering van vis (Aquaculture and labelling of fish). Test-Aankoop 2006; 496:2832.

[22] Karlsen KM, Senneset G. Traceability: Simulated recall of fish products. In: Luten JB, Jacobsen C, Bekaert K, Saebo A, Oehlenschlager J, editors. Seafood research from fish to dish. Quality, safety and processing of wild and farmed fish. Wageningen: Wageningen Academic Publisher, 2006: 251-261.

[23] Central Economic Council (Ministry of Economic Affairs of Belgium). Economical database on seafood products. 2004.

[24] FAO. FISHSTAT Plus Version 2.3. Universal software for fishery statistical time series. 2005.

[25] Raemaeckers M. Contamination data ICES [Personal communication]. Sioen I, 26-4-2005.

[26] Ahmed FE, Anderson RD. Fishery Resources, Consumption and Import Trends, and Biotechnology Developments in the USA. Fish Res 1994; 19(1-2):1-15.

[27] Morrissey MT. Traceability revisited. J Aquat Food Prod Tech 2007; 16(2):1-3.

[28] Verbeke W, Vanhonacker F, Sioen I, Van Camp J, De Henauw S. Perceived importance of sustainability and ethics related to fish: a consumer behaviour perspective. Ambio 2007; 36(7):580-585. 


\section{APPENDIX:}

CEC2000-database: Sp-code $=\operatorname{cod}$

\begin{tabular}{|c|c|c|c|}
\hline \multicolumn{4}{|c|}{ Import data +own landings } \\
\hline SpC-code & Country & Amount (tons) & Ratio (\%) \\
\hline CodTGa & Togo & 1 & $0.00 \%$ \\
\hline CodGRa & Greece & 3 & $0.02 \%$ \\
\hline CodPTa & Portugal & 8 & $0.05 \%$ \\
\hline CodNOa & Noorwegen & 10 & $0.06 \%$ \\
\hline CodESa & Spain & 11 & $0.07 \%$ \\
\hline CodLTa & Lithuania & 11 & $0.07 \%$ \\
\hline CodIEa & Ireland & 13 & $0.09 \%$ \\
\hline CodITa & Italy & 16 & $0.10 \%$ \\
\hline CodLUa & Luxemburg & 22 & $0.15 \%$ \\
\hline CodLVa & Latvia & 27 & $0.18 \%$ \\
\hline CodRUa & Russia & 49 & $0.32 \%$ \\
\hline CodCNa & China & 252 & $1.66 \%$ \\
\hline CodSEa & Sweden & 316 & $2.09 \%$ \\
\hline CodGBa & United Kingdom & 428 & $2.82 \%$ \\
\hline CodPLa & Poland & 715 & $4.72 \%$ \\
\hline CodFRa & France & 752 & $4.96 \%$ \\
\hline CodDEa & Germany & 958 & $6.32 \%$ \\
\hline CodNLa & The Netherlands & 1866 & $12.31 \%$ \\
\hline CodISa & Iceland & 2321 & $15.31 \%$ \\
\hline CodDKa & Denmark & 4384 & $28.92 \%$ \\
\hline \multirow[b]{3}{*}{ STEP 1} & Belgium & 2997 & $19.77 \%$ \\
\hline & Total & 15159 & $100.00 \%$ \\
\hline & & \\
\hline SpC-code & Country & $\begin{array}{r}\text { Amount } \\
\text { (tons) }\end{array}$ & Ratio (\%) \\
\hline CodTGa & Togo & 1 & $0.00 \%$ \\
\hline CodGRa & Greece & 3 & $0.02 \%$ \\
\hline CodPTa & Portugal & 8 & $0.05 \%$ \\
\hline CodNOa & Noorwegen & 10 & $0.06 \%$ \\
\hline CodESa & Spain & 11 & $0.07 \%$ \\
\hline CodLTa & Lithuania & 11 & $0.07 \%$ \\
\hline CodIEa & Ireland & 13 & $0.09 \%$ \\
\hline CodITa & Italy & 16 & $0.10 \%$ \\
\hline CodLVa & Latvia & 27 & $0.18 \%$ \\
\hline CodRUa & Russia & 49 & $0.33 \%$ \\
\hline CodCNa & China & 252 & $1.67 \%$ \\
\hline CodSEa & Sweden & 316 & $2.09 \%$ \\
\hline CodGBa & United Kingdom & 428 & $2.83 \%$ \\
\hline CodPLa & Poland & 715 & $4.72 \%$ \\
\hline CodFRa & France & 752 & $4.97 \%$ \\
\hline CodDEa & Germany & 958 & $6.33 \%$ \\
\hline CodNLa & The Netherlands & 1866 & $12.33 \%$ \\
\hline CodISa & Iceland & 2321 & $15.33 \%$ \\
\hline CodDKa & Denmark & 4384 & $28.96 \%$ \\
\hline & Belgium & 2997 & $19.80 \%$ \\
\hline & Total & 15136 & $100.00 \%$ \\
\hline
\end{tabular}

\section{Export data}

\begin{tabular}{|l|r|r|}
\hline Country & $\begin{array}{r}\text { Amount } \\
\text { (tons) }\end{array}$ & Ratio (\%) \\
\hline Jordan & -1 & $0.02 \%$ \\
\hline Malaysia & -1 & $0.02 \%$ \\
\hline Ukraine & -1 & $0.02 \%$ \\
\hline Sweden & -1 & $0.02 \%$ \\
\hline United Arab Emirates & -2 & $0.04 \%$ \\
\hline Singapore & -2 & $0.04 \%$ \\
\hline Austria & -2 & $0.04 \%$ \\
\hline Romania & -2 & $0.04 \%$ \\
\hline Congo & -2 & $0.04 \%$ \\
\hline Ireland & -4 & $0.09 \%$ \\
\hline Saudi Arabia & -6 & $0.13 \%$ \\
\hline Portugal & -12 & $0.26 \%$ \\
\hline Swiss & -13 & $0.27 \%$ \\
\hline Italy & -16 & $0.33 \%$ \\
\hline Spain & -23 & $0.48 \%$ \\
\hline United Kingdom & -40 & $0.83 \%$ \\
\hline Denmark & -148 & $3.10 \%$ \\
\hline Luxemburg & -194 & $4.04 \%$ \\
\hline Germany & -223 & $4.65 \%$ \\
\hline France & -1391 & $29.02 \%$ \\
\hline The Netherlands & -4791 & $56.52 \%$ \\
\hline Total & & $100.00 \%$ \\
\hline & 5 & \\
\hline
\end{tabular}

Assumption that this did NOT change the ratio of the amount coming from each country of the amount that stayed on the Belgian market 
STEP 2: Looking up the corresponding SpC-code in FAO2000 (here only done for three examples)

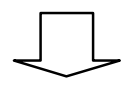

FAO2000-database: Three examples: SpL-code = CodFRa, CodNLa, CodISa

\begin{tabular}{|c|c|c|c|c|c|c|c|c|c|}
\hline SpC-code & 27_01 & 27_02 & 27_04 & 27_05 & 27_06 & 27_07 & 27_08 & 27_12 & Total \\
\hline CodISa & 3963 & & & 234362 & & & & & 238325 \\
\hline CodNLa & & & 5995 & & & 5 & & & 6000 \\
\hline CodFRa & & 2675 & 1222 & 1 & 236 & 7622 & 129 & 1 & 11886 \\
\hline
\end{tabular}

Amount per fishing ground (\%)

\begin{tabular}{|l|r|r|r|r|r|r|r|r|r|r|}
\hline SpC-code & 27_01 & 27_02 & 27_04 & 27_05 & 27_06 & 27_07 & 27_08 & 27_12 & Total & $* * *$ \\
\hline CodISa & $2 \%$ & $0 \%$ & $0 \%$ & $98 \%$ & $0 \%$ & $0 \%$ & $0 \%$ & $0 \%$ & $100 \%$ & $\mathbf{2 3 2 1}$ \\
\hline CodNLa & $0 \%$ & $0 \%$ & $100 \%$ & $0 \%$ & $0 \%$ & $0 \%$ & $0 \%$ & $0 \%$ & $100 \%$ & $\mathbf{1 8 6 6}$ \\
\hline CodFRa & $0 \%$ & $23 \%$ & $10 \%$ & $0 \%$ & $2 \%$ & $64 \%$ & $1 \%$ & $0 \%$ & $100 \%$ & $\mathbf{7 5 2}$ \\
\hline
\end{tabular}

*** Amount imported by Belgium from that country

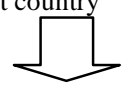

Multiplying the imported amount in ton $(* * *)$ with the relative percentage that was caught or produced by that country over the different fishing grounds: CECFAO database

\begin{tabular}{|l|r|r|r|r|r|r|r|r|r|}
\hline SpC-code & 27_01 & 27_02 & 27_04 & 27_05 & 27_06 & 27_07 & 27_08 & 27_12 & Total \\
\hline CodISa & 39 & 0 & 0 & 2282 & 0 & 0 & 0 & 0 & 2321 \\
\hline CodNLa & 0 & 0 & 1864 & 0 & 0 & 2 & 0 & 0 & 1866 \\
\hline CodFRa & 0 & 169 & 77 & 0 & 15 & 482 & 8 & 0 & 752 \\
\hline
\end{tabular}

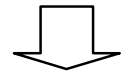

Adding data of Belgian landings for cod to the new composed database, and summing up

\begin{tabular}{|c|c|c|c|c|c|c|c|c|c|c|c|}
\hline SpC-code & & & & $0=$ & & 27_07 & \multicolumn{3}{|c|}{2708} & \multirow{2}{*}{ Total } & \\
\hline & & & & & & & & & & & \\
\hline CodISa & 39 & 0 & 0 & 2282 & 0 & 0 & & 0 & 0 & 2321 & \\
\hline CodNLa & 0 & 0 & 1864 & 0 & 0 & 2 & & 0 & 0 & 1866 & \\
\hline CodFRa & 0 & 169 & 77 & 0 & 15 & 482 & & 8 & 0 & 752 & \\
\hline CodBEa & 0 & 0 & 2648 & 0 & 0 & 341 & & 7 & 0 & 2997 & \\
\hline Subtotal & 39 & 169 & 4589 & 2282 & 15 & 825 & & 6 & 0 & 7935 & \\
\hline \multicolumn{12}{|c|}{ Calculating relative percentages for cod per fishing ground (SUBtotal, since it was only done } \\
\hline SpC-code & 27_01 & 27_02 & 27_04 & 27_05 & 27 & \multicolumn{2}{|c|}{ 27_07 } & 27_08 & \multicolumn{2}{|c|}{ 27_12 } & Total \\
\hline Subtotal & $0.49 \%$ & $2.13 \%$ & $57.83 \%$ & $28.76 \%$ & 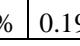 & \multicolumn{2}{|c|}{$10.40 \%$} & $0.20 \%$ & \multicolumn{2}{|c|}{$0.00 \%$} & $100.00 \%$ \\
\hline
\end{tabular}

